\title{
Cost-effectiveness of bioethanol policies to reduce carbon dioxide emissions in Greece
}

\author{
Stelios Rozakis • Md. Imdadul Haque • \\ Athanasios Natsis • Magdalena Borzecka-Walker • \\ Katarzyna Mizak
}

Received: 19 January 2012 / Accepted: 27 June 2012 / Published online: 20 July 2012

(C) The Author(s) 2012. This article is published with open access at Springerlink.com

\begin{abstract}
Purpose The aim of this study was to evaluate the costeffectiveness of bioethanol as regards to its carbon dioxide emissions. The production of the raw material accounts for more than $50 \%$ of the total cost as well as having a significant part of greenhouse gases emitted during the entire process. For this reason, special emphasis is given to a change in agricultural land usage influenced by the demand of biofuel. Therefore, we have estimated the extent of policy influence according to its bioethanol cost-effectiveness. A case study on bioethanol production in an ex-sugar factory in the region of Thessaly, Greece, illustrates the above ideas.

Methods A partial equilibrium micro-economic model of regional supply in the arable farming system of Thessaly was coupled to industrial processing sub-models of bioethanol production from beets and grains. The maximisation of total welfare determines the most suitable crop mix for farmers as well as the lowest cost configurations for industry and, eventually, the minimal level of support by the
\end{abstract}

Responsible editor: Stephan Pfister

\section{S. Rozakis}

Department of Agricultural Economics and Development, Agricultural University of Athens,

Athens, Greece

M. I. Haque

Bangladesh Sugarcane Research Institute,

District- Pabna, Bangladesh

\author{
A. Natsis \\ Department of Natural Resources Management and Agricultural \\ Engineering, Agricultural University of Athens, \\ Athens, Greece \\ M. Borzecka-Walker $(\bowtie) \cdot K$. Mizak \\ Department of Agrometeorology and Applied Informatics, \\ Institute of Soil Science and Plant Cultivation-State Research \\ Institute, Pulawy, Poland \\ e-mail: mwalker@iung.pulawy.pl
}

government for biofuel activity to take off. The environmental performance is assessed under the life cycle assessment (LCA) framework following three interrelated phases: data inventory, data analysis and interpretation. The economic burden to society to support the activity divided by avoided $\mathrm{CO}_{2}$ eq. emissions indicates the bioethanol costeffectiveness, in other words, the cost of greenhouse gases emissions savings.

Results The integrated agro-industry model has been parametrically run for a range of biofuel capacities. A change in direct land use results in lower emissions in the agricultural phase, since energy crops are a substitute for intensive cultivations, such as cotton and corn. A change in indirect land use moderates these estimations, as it takes in account imported food crops that are replaced by energy crops in the region. The savings in cost vary around 160 euros per ton of $\mathrm{CO}_{2}$ eq. for the basic agricultural policy scenario. The current policy that supports cotton production by means of increased coupled area payment has increased up to $30 \%$ the cost of greenhouse gas savings due to bioethanol production.

Conclusions An integrated model, articulating the agricultural supply of biomass with ethanol processing, maximises the total surplus that is under constraints in order to determine the cost-effectiveness for different production levels. Results demonstrate that economic performances, as well as the environmental cost-effectiveness of bioethanol, are clearly affected by the parameters of agricultural policies. Therefore, bioenergy, environmental and economic performances, when based on LCA and the conceptual change in land usage, are context dependent. Agricultural policies for decoupling subsidies from production are in favour of cultivation in biomass for energy purposes.

Keywords Agricultural policy · Ethanol · Cost-effectiveness · Greenhouse gases · Mathematical programming 


\section{Introduction}

Changes in European policies, concerning the sugar and biofuel sectors that completed the Common Agricultural Policy (CAP) reform in 2003, have created favourable environment conditions for ethanol production by European ex-sugar factories, also in countries that had not participated in the first wave of biofuel production in the 1990s. Biofuel activities gained momentum when positive synergies with agricultural policy goals appeared thanks to a pivotal element of the 1992 CAP reforms, namely, the obligatory set aside measure not applied to energy and, in general, industrialised crops. Governments, starting from France, followed by Germany, as well as other countries, proceeded to exempt biofuels from taxes on petroleum products so that they become competitive in the energy market. Complete or partial decoupling of subsidies from production, the basic feature of the 2003 CAP reform has been implemented since the cultivation period 2005-2006. ${ }^{1}$ As a result, gross margins that were earmarked for particular crops have been drastically reduced (i.e. previously heavily subsidised arable crops), consequently decreasing the opportunity cost for the introduction of energy or alternative crops in the cropping plan. Additionally, according to legislative changes for sugar production in the European Union (EU) and the World Trade Organisation, the Common Market Organisation in the EU has excluded the sugar quota restriction (EC 2005) on sugar beet production for non-food use (chemical and pharmaceutical industries and for energy purposes). As a result, several studies have been quickly conducted to evaluate future ethanol production projects and the sugar industry within the EU (Anonymous 2006; Bzowska-Bakalarz and Ostroga 2010). Research has also been conducted in other countries facing similar conditions (Icoz et al. 2009).

Almost two decades after the approval of the tax exemption program in Europe, biofuels are still more costly than fossil fuels, and the agro-energy industrial activity largely depends on government subsidies for its viability. Even if the recent rise in the price of crude oil alleviates the budgetary burden that biofuels represent, the question raised by economists, concerning the efficient allocation of this amount among biofuel chains through tax exemptions to the biofuel processors, is of primary importance. Environmental problems have become more acute, and international commitments mean that a reduction in greenhouse gas (GHG) emissions requires intensified efforts. Assuming that the main positive environmental

\footnotetext{
${ }^{1}$ Decoupling is the removal of the link between direct payments and production. Prior to the reform, farmers received direct payments only if they produced particular commodities. It meant that the profitability of producing a particular product did not depend only on the amount of money for which the farmer could sell the product in the market but also on the amount of the direct payment that was associated with the product.
}

effect of biofuel is a reduction in GHG emissions, the question arises as to whether subsidies for biofuels can be justified on cost-effectiveness grounds. Cost-effectiveness regarding GHG has recently been assessed for biodiesel alternative schemes in Greece (Iliopoulos and Rozakis 2010). In this paper, industrial transformation has been integrated to an agricultural supply model that simultaneously estimates the most suitable bioethanol activity and subsidy levels, as well as the life cycle of greenhouse gas emissions. These elements have been used to evaluate the GHG effectiveness on the conversion of a sugar factory to ethanol production in the region of Thessaly, Greece. In order to estimate the costeffectiveness ratio, the economic costs (budgetary burdens, minus agriculture and industry surpluses) have to be divided by the environmental impact.

It is said that bioenergy is carbon neutral because carbon sequestered from the atmosphere during biomass growth is released when this biomass is used as a solid or liquid fuel after its transformation. However, the production, transportation and processing of biomass requires energy and material inputs, adding directly or indirectly to GHG emissions. Studies on bioethanol (Murphy and McCarthy 2005), which detail agricultural production, transportation, as well as industrial transformation phases, conclude that crop production contributes significantly to the greenhouse effect. Beside fuel used for cultivation operations, emissions due to the application of fertiliser should be considered, including not only fertiliser production but also $\mathrm{N}_{2} \mathrm{O}$ emissions from soils (Brentrup et al. 2000). Greenhouse gas emissions associated with agricultural production depend on the explicit assumptions of land use change ${ }^{2}$ (LUC). One could mention pioneering works concerning Miscanthus in fallow land (Lewandowski et al. 1995) or more recent ones regarding short rotation coppice, Miscanthus and rapeseed, replacing wheat in arable land, grassland or broad-leaved forest (St. Clair et al. 2008); wheat on arable land or grass-covered mineral or peat soil (Börjesson 2009); wheat monoculture (Scacchi et al. 2010) and rapeseed (Malça and Freire 2010) or switchgrass (Cherubini and Jungmeier 2010) on set aside land. Furthermore, it is generally admitted that the greenhouse footprint of biofuels depends to a larger extent on the benchmark situation that may render them good or bad according to Börjesson (2009) and on the implemented methodology as reported by Dorin and Gitz (2008). As a matter of fact, environmental impacts are differentiated if indirect land use changes ${ }^{3}$ are taken into account. According to several studies (Searchinger et al. 2008; Wicke et al. 2008), indirect land use change induced by increasing

\footnotetext{
${ }^{2}$ Direct LUC: Conversion of a land (cultivated land or not) into biofuels production.

${ }^{3}$ Indirect land use change: An energy crop replaces a food crop. The food crop must be produced elsewhere (in a case of a constant food demand).
} 
bioenergy demand may result in important environmental impacts concerning GHG emissions. Current life cycle assessments of GHG effects often fail to take into account indirect LUC (Malça and Freire 2010; Kløverpris et al. 2008a). Recently published research that is related to the current study takes into account the indirect LUC (Russi 2008; Lechon et al. 2011; Tsoutsos et al. 2010), based though on rather arbitrary direct LUC scenarios. In reality, LU changes cannot be considered as direct substitutions, and they rather result from changes in crop rotations. Nevertheless, methodological guidelines are provided by Kløverpris et al. (2008b) in order to determine LUC with prospective or consequential life cycle assessment (LCA), taking market and policy mechanisms into account. As land use modelling is among the most important factors of variability of LC biofuel results (Malca and Freire 2011), the presented study attempts to estimate GHG from bioethanol production with a special emphasis in cropping plan or an estimation into the change of crop rotation change.

For this purpose, the arable land of Thessaly, which provides the raw material for the ethanol plant, is modelled on a microeconomic partial equilibrium approach. The market equilibrium is derived from the maximisation of the agroenergy system welfare that is subjected to technical, institutional, market, agronomic and resource constraints. Taking benefit of a partial equilibrium economic model, we are able to realistically estimate the land use change due to exogenous biomass demand. Biomass demand is created thanks to the conversion of an ex-sugar mill to a bioethanol plant. Coupling the agricultural supply to industry models allows a possibility to consider the impacts of different policies to bioethanol activity. In this context, two variants of CAP are studied, which concern different levels of subsidy coupled for cotton which is the staple crop of the area.

This paper is organised into five sections, including this introduction. Section 2 presents the methodology for integrated sector economic modelling and greenhouse gas emissions estimation. The case study is detailed in the Section 3. The optimisation results are presented in Section 4 with conclusion in Section 5.

\section{Methodology}

2.1 Economic modelling of the biofuel production system

\subsubsection{Industry model}

Industrial models of bioenergy conversion seek to determine the most suitable plant size and appropriate technology. Industrial profit is determined by revenue earned from product and by-product in a year reduced by the total annual cost of the industry. The main relationships, shaping the feasible area, deal with capacity and sugar beet to wheat ratio in order to ensure the maximum duration of operation during the year (330 days), in addition to capital cost linked to its size (average capital cost is decreasing for increasing ethanol capacities). Usually, size determination is modelled by binary or integer variables, as in a bioenergy application (Mavrotas and Rozakis 2002) that also mentions a number of studies of the same kind. In this study, since a continuous relationship is available (Soldatos and Kallivroussis 2001), we opted for introducing exponential terms (scale coefficients) in the objective function, rendering the industrial module non-linear. Furthermore, feedstock supply, i.e. wheat and sugar beet produced in farms, has to satisfy industry needs (raw material demand should be greater than the supply). A number of balance constraints, concerning by-products, material inputs and environmental balances, complete the model structure. Detailed information is included on capital and administrative costs (which decrease with plant size), on variable conversion costs (proportional to the output) as well as on transport costs (increasing with plant size). The model specification is detailed in Haque et al. (2009).

Raw material costs are often assumed as proportional to the output, and the biomass price is perfectly elastic, therefore constant, no matter what quantity is demanded by the plant. A typical example of this engineering approach for plant size optimisation is a model by Ngyen and Prince (1996) on bioethanol from sugarcane and sweet sorghum in Australia. However, we would expect that over a certain demand level, marginal increases in biomass quantity would result in a higher price to pay to acquire it. This idea recalls the concept of a supply curve that is determined through parametric optimisation of agricultural sector models.

\subsubsection{The agricultural sector model}

Partial equilibrium micro-economic models of the farm sector are coupled to industry models to analyse the introduction of energy crops in the crop mix. For instance, Treguer and Sourie (2006) have estimated the agricultural surplus generated by the production of energy crops, including sugar beet to ethanol for French arable areas, and assessed how these new crops can help to maintain farmer's income and farm structure. A large number of individual farms are used so as to adequately represent region's arable agriculture. Each farm selects a set of activities (cropping plan) in order to maximise the gross margin. The gross margin for a farm is determined by the total revenue earned from selling products and by-products reduced by the variable cost. Farm planning is governed by resource availability and technical and policy constraints. The main constraints are: available land (both total land area and area by land type, such as irrigated, non-irrigated, etc.), irrigation water availability, crop rotation, market quota, market flexibility and policy (such as cross-compliance) constraints. 


\subsubsection{Biofuel chain economics and deadweight loss}

Ethanol production triggered by the tax credit policy, as well as the subsequent demand on raw material by the ethanol plant and farmers' responses, regarding cultivation decisions concerning crop mix and rotation, is determined as the optimum by the model integrating industry module to the agricultural sector model. The chain objective function represents a total agents' surplus that is the sum of the surplus (gross margin) generated from agriculture and profit earned by the industry. Parametric optimisation of the integrated model for different biofuel production levels provides data for a marginal analysis; in other words, they determine the marginal cost or supply curve (HM curve in Fig. 1).

One can observe that the biofuel cost is higher than its market value (ex-refinery fossil fuel price OB), so policies to support biofuel takeoff opted for tax exemptions from special taxes to fossil fuels. Actually, the fossil fuel price for the consumer $(\mathrm{OK})$ is much higher than its cost $(\mathrm{OB})$, due to general and specific taxes amounting at $\mathrm{BK}$ in the graph that illustrates usual situations in most developed countries. In this case, for the Q quantity level, a unitary tax credit of at least $\mathrm{AC}$ is required to render biofuel equally profitable as its fossil competitor. Quantity exempted from tax is estimated by policy makers on the basis of the earmarked budget for biofuels. If for instance, a budget dedicated to biofuel amounts at area BCDK (unitary tax $\mathrm{CD}$ ) then the eligible quantity equals $\mathrm{OQ}$. Then, the surplus for the agricultural sector is equal to the area HGM and for the industry to EFAD. The loss for the economy (deadweight loss), due to the voluntary policy supporting biofuel activity, is the difference between total budgetary expenses and agents' total surplus. The integrated model can minimise the economic cost, selecting the most efficient production system and simultaneously determining the biofuel quantities and tax exemption values per unit of biofuel volume, given the fixed amounts of government expenditure. To estimate the cost

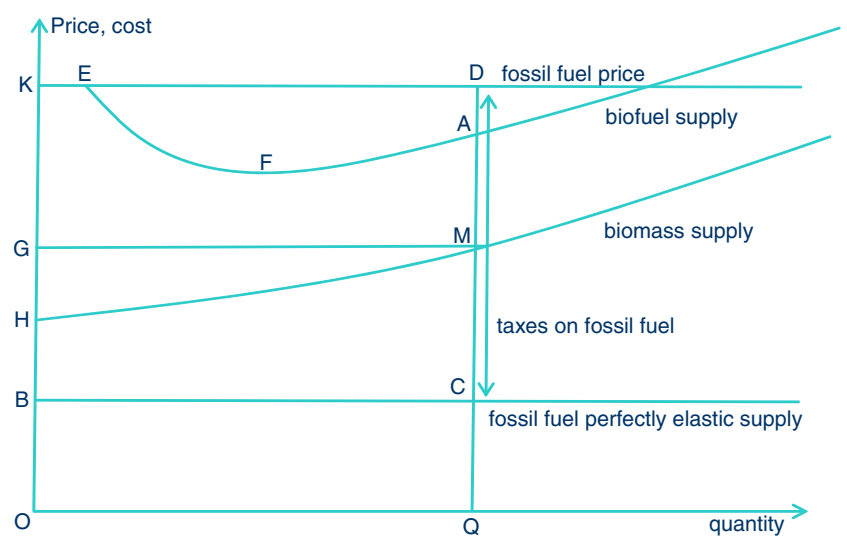

Fig. 1 Biofuel economics: demand line and supply curves of $\mathrm{CO}_{2}$ emissions savings per unit and subsequent costeffectiveness, the net savings have first to be calculated in physical units.

\subsection{Life cycle estimation of GHG emissions in ethanol production system}

\subsubsection{Life cycle calculation background}

The concepts of "foreground" and "background" proposed within the environmental systems analysis theory are very useful since they help to distinguish between unit processes of direct interest in the study and other operations with which they exchange materials and energy (Clift et al. 2000). The foreground may be defined as the endogenous part of the production chain, which includes a set of processes whose selection or mode of operation is affected directly by the decisions of the study. The background denotes the exogenous parts of the production chain, comprising all other processes that interact directly with the foreground system, usually by supplying material or energy to the foreground or receiving material and energy from it. These concepts are illustrated in Fig. 2, adapted in the bioethanol production case.

Direct and indirect fossil energy used along the ethanol production chain is reported in primary energy sources terms. Fossil energy is calculated on the basis of the amount of fuel and fertiliser used in the biomass production process. In addition, GHG emissions from nitrous oxide are assessed. Soil carbon loss while converting land uses is significant in cases of forest and grassland converted to arable land. In addition, conversion from conventional to reduced tillage accumulates soil carbon. Crop conversion under the same tillage practice is assumed to have no effect. GHG costs related to the manufacture of farm machinery and buildings have no effect since they are likely to be similar for the baseline land use (arable crops). Other substances, such as pesticides and herbicides, are not included in this analysis due to a lack of data. In any case, this emission only marginally affects the overall emissions, as relevant papers on these substances report minimal GHG impact (St Clair et al. 2008).

The energy used in industrial processing is also calculated on the basis of primary energy. For example, steam power is used for industrial processing, and steam is generated by diesel fuel.

Life cycle emissions factor is used to calculate the $\mathrm{CO}_{2}$ emissions from respective energy sources. Both direct emissions from combustion and indirect emissions prior to combustion emitted for extraction, collection and refinement for transportation to a consumer of the fuel (DEFRA 2010) are considered as including net $\mathrm{CO}_{2}$, $\mathrm{CH}_{4}$ and $\mathrm{N}_{2} \mathrm{O}$ emissions. 
Fig. 2 Foreground and background system for bioethanol production

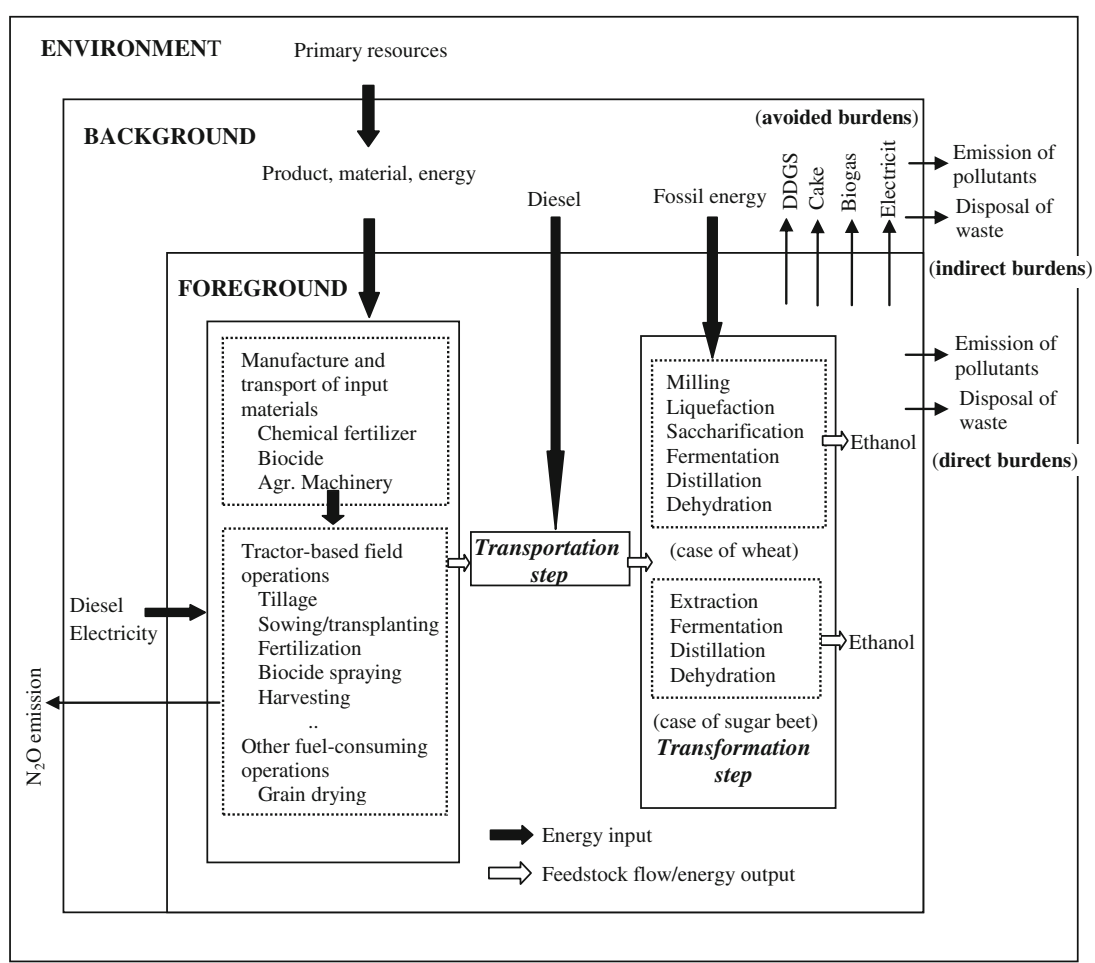

\subsubsection{GHG emissions in agricultural production}

To assess GHG emissions in agricultural production, all operational activities, such as ploughing, sowing/transplantation, fertilisation, irrigation, harvesting, etc. and input/material associated with crops cultivated in the region (both conventional and energy crops), have been taken into consideration. Carbon dioxide emissions from machinery operation are calculated by the amount of fuel (diesel) used, multiplied by the emissions factor. To calculate the emissions from fertiliser, the amount of fossil energy used to produce fertiliser needs to be accounted for. Natural gas, coal and oil are used for the production of different fertilisers. Fossil energy requirement for fertiliser and associated $\mathrm{CO}_{2}$ emissions is presented in Table 1. Calculation of the total GHG emissions for different fertiliser contents (last row in
Table 1) can be presented with the following matrix notation:

$$
\begin{aligned}
\mathrm{GHG}_{\text {emiss }}(\text { element })= & \text { unit } \mathrm{GHG}_{\text {emiss }}(\text { energy type }) \\
& \times \text { energy content (energy type, element }) .
\end{aligned}
$$

The row vector contains emission factors, i.e. kilogram $\mathrm{CO}_{2}$ emissions per kilogram fossil energy (natural gas, oil and coal, respectively), whereas fertiliser 'energy content' matrix contains required amount (kilogram) of fossil energy (natural gas, oil and coal, respectively) for the production of $1 \mathrm{~kg}$ fertiliser $\left(\mathrm{N}, \mathrm{P}_{2} \mathrm{O}_{5}\right.$ and $\left.\mathrm{K}_{2} \mathrm{O}\right)$ in column.

$\mathrm{N}_{2} \mathrm{O}$ and carbon dioxide equivalent emissions caused by fuel and fertiliser use (including fertiliser production and nitrous oxide from soils) are calculated for all crops
Table 1 Primary energy $\mathrm{CO}_{2}$ emissions and fossil energy requirements (Malça 2002)

\begin{tabular}{llllll}
\hline Primary energy type & $\begin{array}{l}\text { LCA CO} \\
\text { coefficient }\end{array}$ & $\begin{array}{l}\text { Elements }(\mathrm{kg}) \text {, primary } \\
\text { energy input }(\mathrm{kg})\end{array}$ & $\mathrm{N}$ & $\mathrm{P}_{2} \mathrm{O}_{5}$ & $\mathrm{~K}_{2} \mathrm{O}$ \\
\hline Natural gas & $3.116 \mathrm{~kg} \mathrm{CO}_{2} / \mathrm{kg}$ & Natural gas & 0.947 & 0.226 & 0.143 \\
Diesel fuel & $3.45 \mathrm{~kg} \mathrm{CO}_{2} / \mathrm{kg}$ & diesel fuel & 0.0546 & 0.188 & 0.0334 \\
Coal & $2.83 \mathrm{~kg} \mathrm{CO}_{2} / \mathrm{kg}$ & Coal & 0.0254 & 0.0306 & 0.0316 \\
Gasoline & $3.152 \mathrm{~kg} \mathrm{CO}_{2} / \mathrm{kg}$ & & & & \\
Electricity & $0.618 \mathrm{~kg} \mathrm{CO}_{2} / \mathrm{kWh}$ & & 3.211 & 1.44 & 0.65 \\
Total emission $\left(\mathrm{kg} \mathrm{CO}_{2} / \mathrm{kg}\right)$ & & & & \\
\hline
\end{tabular}


present in the addition crop mix of the region under study. Calculation of GHG emission for fertiliser for different crops can be presented with the following matrix notation:

$\mathrm{GHG}_{\text {fert }}($ crop $)=\mathrm{GHG}_{\text {emiss }}($ element $) \times$ input $($ element, crop $)$.

' $\mathrm{GHG}_{\text {emiss' }}$ 'vector values calculated via Eq. 1 (last line of Table 1) denote emissions per active element within fertilisers. The matrix of input requirements (elements $\times$ crops) is identified in Table 2 for the region of study comprising material and fuel inputs for cultivated crops.

$\mathrm{N}_{2} \mathrm{O}$ emission from additions of nitrogenous fertiliser to land due to deposition and leaching are also estimated. Here, emissions of nitrous oxide from land are estimated from the latest Intergovernmental Panel on Climate Change (IPCC) model (IPCC 2006). According to the IPCC model, $1 \%$ of nitrogen fertiliser used is directly emitted as $\mathrm{N}_{2} \mathrm{O}$, and $1 \%$ of direct emissions are emitted indirectly. The greenhouse potentials of $\mathrm{N}_{2} \mathrm{O}$ is 296 times of $\mathrm{CO}_{2}$ (IPCC 2006).

When the most suitable crop mix is determined for wholefarm budgeting models like linear programming ones and then due to the constraint structure, the cultivation of a new crop may result in combinations of cultivation replacements. Emissions are then calculated as differentials based on crop greenhouse gases coefficients and marginal changes in crop mix at a farm level, analogous to the substitution method. Therefore, depending on various energy intensities of different crops, an introduction of an energy crop in the plan could reduce the overall emissions, provided that the new crop rotation is less intensive compare to the previous one.

\subsection{3 $\mathrm{CO}_{2}$ emissions in subsequent phases}

GHG emissions during transportation and industrial transformation are proportional to the ethanol produced. Emissions during the industrial processing are largely dependent on what fuel is used to produce the heat, steam and electricity required for manufacture of bioethanol. Energy input for the transformation process is assumed to be the largest part in the bioethanol production system. Hence, efficient industrial processing systems for bioenergy can drastically improve GHG balance (Koga 2008).

To estimate the saving of GHG in the final stage (fuel combustion), life cycle GHG emissions of gasoline are considered as a reference for a comparison with ethanol (3.152 $\mathrm{kg} \mathrm{CO}_{2} / \mathrm{kg}$ gasoline, see Table 1). Hence, it is necessary to derive a fuel equivalency ratio between ethanol and gasoline. This depends on the blends and on the type of vehicle engine, increasing with a lower ethanol percentage in the blend. Warnock et al. (2005) mentioned that the fuel efficiency of automobiles is reduced by $27 \%$ on E85 compared to pure gasoline. Macedo et al. (2008) adopted an equivalence of 11 ethanol (anhydrous) to 0.81 gasoline for E25; Nguyen and Gheewala (2008) refer to 0.89 for E10. For blends less than E10, Macedo et al. (2008) consider an equivalent of $1: 11$, whereas it can even be marginally better $(1.04: 11)$ in a spark-ignition engine. Considering that ethanol production in Greece may reach at best, to a mere $5 \%$, we have adapted our calculations to an equivalent of $1: 1$. Using specific gravities $(0.73722$ and $0.78506 \mathrm{~kg} / \mathrm{l}$ for gasoline and ethanol, respectively), we conclude that $1 \mathrm{~kg}$ of ethanol replaces $0.939 \mathrm{~kg}$ of gasoline in $\mathrm{E} 5$ blends; this ratio is used in calculations to determine $\mathrm{CO}_{2}$ emissions.

\section{Results for the Thessaly region case study}

\subsection{Agricultural sector to supply biomass for energy}

Between the cultivating period of 2001 and 2002, data on farm the structure, costs and yields for farms, which cultivated for at least one stremma (Greek term counting for one tenth of a hectare) of cotton or sugar beet, were used in the case study. A group of 344 arable farms out of the 22,845 farms of the region monitored by the Farm Accountant Data Network satisfied the above constraint. The main crops cultivated by those farms are: soft wheat, durum wheat, maize, tobacco, cotton, dry cotton, sugar beet, tomato, potato, alfalfa, fodder maize and intercropped vetch to conform with the cross-compliance term of the new Common Agricultural Policy. The identifying data items by crop and by agricultural farm in the sample

Table 2 Average fossil input requirement for crop cultivation

\begin{tabular}{|c|c|c|c|c|c|c|c|c|c|c|c|}
\hline \multirow[t]{2}{*}{ Item } & \multicolumn{11}{|l|}{ Crops } \\
\hline & Soft wheat & Durum wheat & Irrigated wheat & Maize & Tobacco & Cotton & Potato & Sugar beet & Tomato & Maize (fodder) & Alfalfa \\
\hline Diesel (1/ha) & 49 & 49 & 55 & 160 & 236 & 199 & 269 & 114.1 & 269 & 160 & 81 \\
\hline $\mathrm{N}(\mathrm{kg} / \mathrm{ha})$ & 124 & 124 & 124 & 334 & 180 & 206 & 164.5 & 110 & 180 & 334 & 55 \\
\hline $\mathrm{P}_{2} \mathrm{O}_{5}(\mathrm{~kg} / \mathrm{ha})$ & 20 & 20 & 20 & 100 & 80 & 80 & 89 & 40 & 80 & 100 & 180 \\
\hline $\mathrm{K}_{2} \mathrm{O}(\mathrm{kg} / \mathrm{ha})$ & 0 & 0 & 0 & 0 & 100 & 60 & 175 & 100 & 100 & 0 & 0 \\
\hline
\end{tabular}


were: yield (kilogram/hectare), prices $(€)$, subsidy ( $€$ /kilogram and $€ /$ hectare depending on the type of crop) and the variable costs $(€ /$ hectare). Variable cost includes: seeds and seedlings purchased, fertilisers and soil ameliorants, protection chemicals, fuels and lubricants, electrical energy, water, running maintenance of equipment, maintenance of buildings and land improvements, salaries, social taxes as well as the wages of hired labour.

It is assumed that farms, holding a sugar beet quota in 2002 and possessing considerable experience on its cultivation (since they had multi-year contracts with the sugar industry), will be the first and presumably most efficient suppliers of the ethanol plant with sugar beet. However, ethanol, exclusively from sugar beet processing, cannot last for more than 3 months due to its perishable nature. In order to ensure profitability for the ethanol plant, it is important to spread capital and administrative charges over a longer period. This suggests the attractiveness of using mixed crops, in this case, sugar beet and grains, in order to extend the processing season to 330 days per year. The cultivation of wheat in irrigated plots is considered as the most suitable method to supply ethanol plant by grains. This is because: first, the output is much higher than that of non-irrigated wheat, and secondly, it allows an opportunity for an extensive cotton cultivation replacing the monoculture with a cotton-wheat rotation (Rozakis et al. 2001), holding beneficial effects on a cropping system's sustainability.

\subsection{Sugar industry converted to ethanol production unit}

Technical and economic data for the production process of ethanol and the determination of various costs for the industry model are drilled by Soldatos and Kallivroussis (2001) and adapted to the conditions of ex-sugar factory in Thessaly by Maki (2007). The conversion of a sugar plant to an ethanol production plant obviously needs some modification and addition to the existing facilities and equipment. Additional activities and equipment that is required for the production of ethanol from sugar beet concerns: fermentation, distillation, dehydration, recovery, storage, instrumentation, quality control and shipment of ethanol. On the other hand, ethanol production from wheat requires additional processes and equipment like: grinding of grain, pulping, starch hydrolysis and saccharification with enzymes.

The base capacity of the unit $(35,000 \mathrm{t} \mathrm{EtOH})$ determines the cost of investment, including the cost of equipment, the requirements for the workforce, costs (direct and indirect) that concern the economic analysis as well as a pattern into the final cost of the first and auxiliary matters, the cost of electrical energy and steam and the cost of maintenance plus other costs of operations that concern the production and the administrative support of the unit. A scale coefficient of 0.61 is used as an exponential function linking capital costs to plant capacity, denoting increasing costs at a decreased growth rate. The allowable capacity sizes vary from 10,000 to $120,000 \mathrm{t}$. Furthermore, the transformation ratios for both chains are included, namely, wheat and sugar beet to ethanol, and corresponding prices, as well as required quantities (per produced quantity of ethanol) of additional auxiliary, matter. These include chemical substances, requirements for electrical energy and steam, including the corresponding costs, production rate of by-products and the sale prices of any produced ethanol and by-products.

\subsection{Calculation of GHG emissions}

Aggregate greenhouse gases emissions from fuel and fertiliser $\left(\mathrm{GHG}_{\text {fert }}\right.$ from Eq. 2) in kilogram per hectare appear in the first part of Table 3 . The total nitrous oxide emissions for the cultivation of 1 ha of land range from less than $1 \mathrm{~kg}$ to about $4 \mathrm{~kg}$. The highest emission per hectare is found in maize production, and the lowest is in alfalfa cultivation (second part in Table 3).

Certainly, GHG differentials, when converting them from grassland to intensive energy cropping, are spectacular at the expense of energy crops; however, even displacements and replacements among arable crops reveal significant differences in GHG costs or gains. For instance, if wheat is used as a substitute for cotton in an irrigated plot, the overall $\mathrm{CO}_{2}$ emissions are reduced by $1,156 \mathrm{~kg}$ per ha (see last line of Table 3: $1,017-2,173=-1,156 \mathrm{~kg} \mathrm{ha}^{-1}$ ). On the contrary, the substitution of sugar beet for alfalfa results in increased emissions. In a mathematical programming context, when a marginal land use changes due to the introduction of energy crops and is determined by the regional agriculture supply model (income maximisation under constraints), GHG costs or gains are simultaneously calculated at an optimum. The aggregate results are then converted in an ethanol ton basis in order to calculate the total GHG emissions for bioethanol production.

The industrial processing stage is responsible for a major part of the emissions, followed by the agricultural sector for biomass production and then by transportation. $\mathrm{CO}_{2}$ eq. emissions are proportional to the plant size, i.e. the total $\mathrm{CO}_{2}$ eq. emissions increase as the plant size gets bigger. The data for the required steam and electricity, as well as $\mathrm{CO}_{2}$ emissions for the industrial processing of 1 ton of ethanol produced from wheat and sugar beet, are shown in Table 4 . To calculate the overall emissions, one should weigh the wheat/beet ratio.

\subsection{Policy measures and CAP evolution}

It should be noted at this point that the differentials in the crop mix with and without the cultivation of the energy crop may be influenced by policy parameters. As a matter of fact, 
changes in the European Common Agricultural Policy have, several times, altered the 'reference system' upon which the GHG emissions of the biomass to energy are measured. One can mention a study that estimates the supply curves of solid biomass to electricity in showing a net displacement decline due to the CAP reform in 2003 (Lychnaras and Rozakis 2006). In 2008, because of serious concerns for the viability of the cotton sector, a partial-coupled subsidy was increased by 25 euros per ha, resulting in significant increases in the cultivation of cotton and subsequent rise in the opportunity cost for the energy crops.

\subsection{Quantitative impacts in the region of study}

Table 5 shows the most suitable cultivated surfaces at a regional scale for selected policy variants, namely, 'CAP 2006' (decoupling except cotton that enjoys area support of 55 euros $^{-1} \mathrm{a}^{-1}$ ), 'CAP 2006 eth' (same agricultural policy plus demand for ethanol thanks to the tax credits), CAP 2009 (decoupling except cotton that enjoys area support of 80 euros ha ${ }^{-1}$ ) and 'CAP 2009 eth' (same variant of agricultural policy plus demand for ethanol thanks to the tax credits). Surfaces that can be classed as differential reveal that substitutions caused by an energy crop demand of identical ethanol capacity, presenting different patterns. The biomass that is needed to supply a capacity of $120 \mathrm{kt}$ of ethanol is about $46.22 \mathrm{kha}$ wheat and $6.98 \mathrm{kha}$ sugar beet. Energy crops replace soft and durum wheats, maize and last, but not least, cotton. An alfalfa-cultivated area is increased in the crop plan with energy crops due to cross compliancy constraints. Consequently, in order to estimate the GHG emissions, one should first subtract the ones that are substituted for cereals and cotton from those generated during the cultivation of energy crops and additional alfalfa areas. GHG emissions due to the cultivation of energy crops approximately amount to $55.59 \mathrm{kt} \mathrm{CO}_{2}$ eq. $(1,017 \times 46.22+$ $1,228 \times 6.98)$, whereas if the substitutions are taken into account, we can observe emission savings amounting to $45.2 \mathrm{kt}$ (vector product of unitary emissions from last line of Table 3 and the differential CAP 2006 surfaces from Table 5) and $60.5 \mathrm{kt} \mathrm{CO}_{2}$ eq. for policy regimes $\mathrm{CAP}$ 2006 and CAP 2009, respectively. The savings are much higher in the second scenario because the initial crop mix includes large areas of cotton, as one can verify in Table 5, which are more intensive than cereals.

The parametric optimisation of the integrated agroindustrial model has determined the most suitable crop mix for farmers and technology configuration for the industry as well as the size of the plant. The main cost categories include labour, variable input, raw material, capital amortisation and other operational costs (see Table 6 for different plant sizes). As expected, the average biomass costs increase, and transformation costs decrease with capacity in 
Table $4 \mathrm{CO}_{2}$ emissions in the industry for the production of 1 ton ethanol

\begin{tabular}{lllllll}
\hline & Operation & Fuel ratio & Input ratio & Energy input (t or kWh) & Unit emission & Total emission (kg/t EtOH) \\
\hline Wheat processing & Steam & 0.072 & 5 & 0.36 & 3,450 & 1,242 \\
& Electricity & & & 503 & 0.618 & 310.85 \\
Beet processing & Steam & 0.072 & 4.42 & 0.32 & 3,450 & 1,097 \\
& Electricity & & & 228.7 & 0.618 & 141.34 \\
\hline
\end{tabular}

every case. Biomass costs are endogenously derived by the model (dual prices), resulting from changes in the crop mix to satisfy the increasing biomass demand from the industry. The feedstock supply curve, derived from dual prices of sugar beet and wheat demand-supply constraints, has a positive slope. The model maximises the total profit; thus it proposes the highest possible capacity within a predetermined range. The key results of the model, concerning the original configuration, are presented in Fig. 3. One can observe that the raw material cost is a major part of the total cost that is increasing with a plant's size. The total average cost is minimised according to a capacity range for $50 \mathrm{kt}$ of ethanol. Clearly, the average capital costs begin at $16.1 \mathrm{c} . / 1$ for small plants $(10,000 \mathrm{t})$ and decrease to $8 \mathrm{c} . / 1$ for maximal capacity $(120,000 \mathrm{t})$. Sugar beet and wheat amount to almost $40 \%$ of the total cost for small plants $(10,000 \mathrm{t})$, but this element increases to $60 \%$ for $120,000 \mathrm{t}$ plants.

The $\mathrm{CO}_{2}$ cost saving is estimated on the basis of deadweight loss that the society has to pay for the bioethanol production activity. Deadweight is the forgone benefit that the taxpayers have to bear. The surplus generation and deadweight loss of bioethanol production activity are presented in Table 7. It is observed that, at the most suitable plant size of $120 \mathrm{kt}$ ethanol under the policy of a subsidy on cotton cultivation at 55 euros per ha (CAP 2006), the cost of ethanol production per litre is 0.687 euro per litre, where as the cost of a gasoline equivalent amounts to 0.42 euro; therefore, a 0.267 euro per litre subsidy is required for ethanol to be competitive with gasoline. The total amount of subsidy for $120 \mathrm{kt}$ of bioethanol is estimated at 40.48 million euros. For any tax exemption level higher than that, the industry then provides a surplus. For instance, a 40 c. tax exemption level results in $20.09 \mathrm{M}$ euros benefit for the industry. The agricultural sector also generates 7.04 million euros from feedstock sales over the production cost. The net loss of the society is derived by deducing the total surplus gain by industry and agriculture from the total subsidy paid for ethanol activity. The deadweight loss for the optimum plant capacity is estimated at 33.45 million euros. For the same amount of ethanol production under a scenario of subsidy on cotton at 80 euros per ha (CAP 2009), the agricultural surplus increased substantially, but also the total subsidy requirement rises because of the high cost of the raw material, and the deadweight loss increases at a $41.86 \mathrm{M}$ euros level. Therefore, the agricultural policy is an important factor that drives the ethanol competitiveness and deadweight loss for the society as well, whereas, an energy policy (tax exemption levels) only affects the industry surplus. Emissions due to the transportation of the raw material are estimated in a similar manner as those concerning the cultivation, taking into account substitutions among crops (unitary values in Table 3 ).

Firstly, the $\mathrm{CO}_{2}$ eq. emissions are estimated, considering the direct land use change for feedstock production plus emissions for transportation and for industrial transformation. In this scenario (direct LUC), a change in the crop mix is taken into consideration, and the GHG differentials for with and without the cultivation of energy crops are evaluated within the regional boundaries of Thessaly. In the second scenario, indirect land use change is also considered, taking into account: (1) reductions in cereal quantities lead to an increase of imported cereals from Eastern Europe; (2) the cotton quantity is reduced and results in the local ginning industry downgrading with no additional imports, and

Table 5 Policy-dependent surfaces cultivated by arable crops

\begin{tabular}{llllllllllll}
\hline $\begin{array}{l}\text { Optimal solution: aggregate crop } \\
\text { mix (in k ha) }\end{array}$ & $\begin{array}{l}\text { Soft } \\
\text { wheat }\end{array}$ & $\begin{array}{l}\text { Durum } \\
\text { wheat }\end{array}$ & $\begin{array}{l}\text { Irrigated } \\
\text { wheat }\end{array}$ & Maize & Tobacco & Cotton & POTATO & $\begin{array}{l}\text { Sugar } \\
\text { beet }\end{array}$ & $\begin{array}{l}\text { Tomato } \\
\text { (fodder) }\end{array}$ \\
\hline CAP 2006 & 28.43 & 59.39 & 0 & 42.29 & 0 & 82.64 & 0.124 & 0 & 0.413 & 0 & 51.07 \\
CAP 2006 eth & 21.61 & 45.39 & 46.22 & 31.03 & 0 & 59.93 & 0.124 & 6.98 & 0.413 & 0 & 52.66 \\
Differential 2006 & -6.82 & -14.0 & 46.22 & -11.2 & 0 & -22.71 & 0 & 6.98 & 0 & 0 & 1.581 \\
CAP 2009 & 17.9 & 35.36 & 0 & 16.1 & 0 & 157.2 & 0.124 & 0 & 0.413 & 0 \\
CAP 2009 eth & 17.20 & 30.14 & 45.78 & 11.04 & 0 & 111.9 & 0.124 & 6.91 & 0.413 & 0 & 47.31 \\
Differential 2009 & -0.68 & -5.22 & 45.78 & -5.06 & 0 & -45.3 & 0 & 6.91 & 0 & 0 & 3.54 \\
\hline
\end{tabular}


Table 6 Cost items in euro per litre of ethanol

\begin{tabular}{lllllll}
\hline Capacity & 10 & 20 & 30 & 40 & 50 & 60 \\
\hline Capital cost & 0.161 & 0.123 & 0.105 & 0.094 & 0.086 & 0.080 \\
Labour cost & 0.042 & 0.025 & 0.019 & 0.016 & 0.013 & 0.012 \\
Raw material cost (2009) & 0.330 & 0.349 & 0.380 & 0.402 & 0.417 & 0.429 \\
Variable input cost & 0.188 & 0.188 & 0.188 & 0.188 & 0.188 & 0.188 \\
Other costs & 0.035 & 0.027 & 0.023 & 0.021 & 0.019 & 0.018 \\
Total cost & 0.756 & 0.712 & 0.715 & 0.720 & 0.723 & 0.727 \\
\hline
\end{tabular}

(3) cake for feedstock is produced by the ethanol plant substitutes for soya cake that is currently imported.

The introduction of energy crops in the model changes the crop mix that creates imbalances in the market supply and demand. For example, in the new cropping mix after the introduction of energy crops, cotton, maize, soft wheat, durum wheat, the cultivation area is replaced by irrigated wheat and sugar beet that will be used for bioethanol production. A shortage of wheat and maize for food must be met with imports. Wheat and maize imports from Eastern Europe would be the most suitable for Greece, and that is assuming that there is an availability of land for wheat and maize cultivation in Eastern Europe and also moderate transportation cost. Life cycle GHG emissions for wheat and maize production in Eastern Europe is different from Greece because fossil energy usage and yield in agricultural production are different as calculated from the BioGrace GHG calculation database (BioGrace 2010). Moreover, the activity of bioethanol production produces distilled dried grain soluble (DDGS), a high value animal feed as by-product that is a substitute for soya cake. The avoided $\mathrm{CO}_{2}$ due to reduction of soya cake import is also incorporated. In terms of nutrient (protein) content, the ratio of soya cake replaced by DDGS is considered 0.78:1.

The results on GHG emissions in different scenarios are presented in Table 8. Under the scenario of direct LUC, the

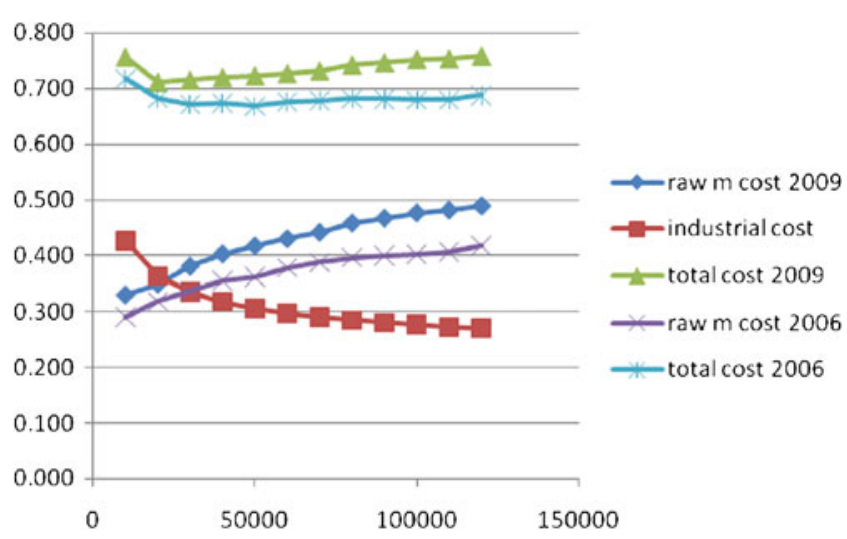

Fig. 3 Cost allocation in euro per litre of ethanol against capacity in the horizontal axis (for different agricultural policy schemes) net $\mathrm{CO}_{2}$ emissions change in agriculture, and transportation is estimated by the differences in $\mathrm{CO}_{2}$ emissions with and without ethanol production. The introduction of energy crops reduces the $\mathrm{CO}_{2}$ emissions in agriculture. One can observe that on an average feedstock production, agriculture contributes to $24 \% \mathrm{CO}_{2}$ eq. emissions; $75 \%$ of the emissions occurred in industrial processing, whereas only $1 \%$ is dedicated for transportation. With the most suitable plant size of $120 \mathrm{kt}$ ethanol per year, $340.4 \mathrm{kt} \mathrm{CO}_{2}$ emissions caused by gasoline can be avoided by replacing it with ethanol. The total net $\mathrm{CO}_{2}$ emissions, including emissions saved due to the replacement of gasoline by ethanol at the most suitable plant size of $120 \mathrm{kt}$, appeared to be $171.9 \mathrm{kt}$ that contributed 1,432 ton $\mathrm{CO}_{2}$ saving per ton of ethanol production. Under the second scenario, we considered indirect land use change including import and import substitution. The total $\mathrm{CO}_{2}$ saving at the plant size of 120 is $172.6 \mathrm{kt}$ that contributed 1,438 ton $\mathrm{CO}_{2}$ saving per ton of ethanol.

In the case of direct land use change within the regional boundary of Thessaly, the cost in $\mathrm{CO}_{2}$ saving varies around 160 euros per ton saved for plant capacities of 60-120 kt. When considering indirect land use change, the import and import substitution trend of the cost in $\mathrm{CO}_{2}$ saving are hardly different, moving to 159 euros per ton $\mathrm{CO}_{2}$ eq.

When an agricultural policy is modified with regards to the area subsidies for cotton, this, as previously explained, alters the regional crop mix and increases the opportunity cost of land for energy crops. Then, unitary emissions become lower than those under CAP 2006 for the same capacity $(120 \mathrm{kt})$, but when we consider indirect LUC, the unitary emissions become higher (last column in Table 8). The monetary cost per ton of $\mathrm{CO}_{2}$ eq. is also increased by 32 and $11 \%$ for direct and indirect land use, respectively, amounting to about 212.5 and 177 euros per ton saved, respectively.

It should be noticed at this point that the price of $\mathrm{CO}_{2}$ eq. offset at the European Climate Exchange was on average at 16.5 euros per ton in the period 2008-2009. So even in the best case, one could have purchased ten times as many tonnes of carbon dioxide offsets for the same amount of public funds. However, when our findings are compared with alternative biofuel chains, such as biodiesel, the bioethanol in ex-sugar mills seems interesting. Compared to the 
Table 7 Surplus generation and deadweight loss (in M euro) of bioethanol production

\begin{tabular}{|c|c|c|c|c|c|c|c|c|}
\hline \multirow{2}{*}{$\frac{\text { Item }}{\text { Plant size (kt) }}$} & \multicolumn{4}{|c|}{ Under subsidy on cotton at $55(€ / \mathrm{ha})$} & \multicolumn{4}{|c|}{ Under subsidy on cotton at 80 ( $€ /$ ha) } \\
\hline & 60 & 80 & 100 & 120 & 60 & 80 & 100 & 120 \\
\hline Ethanol cost (euro per litre) & 0.676 & 0.681 & 0.679 & 0.687 & 0.727 & 0.743 & 0.752 & 0.758 \\
\hline Differential ethanol-gasoline (euro) & 0.256 & 0.261 & 0.259 & 0.267 & 0.307 & 0.323 & 0.332 & 0.338 \\
\hline Subsidy requirement (1) (in $\mathrm{M} €$ ) & 19.36 & 26.36 & 32.63 & 40.48 & 23.22 & 32.57 & 41.91 & 51.21 \\
\hline Total subsidy (2) $(\mathrm{M} €)$ & 30.29 & 40.38 & 50.48 & 60.58 & 30.29 & 40.38 & 50.48 & 60.58 \\
\hline Industry surplus $(3)(\mathrm{M} €)^{\mathrm{a}}$ & 10.93 & 14.02 & 17.85 & 20.09 & 7.07 & 7.82 & 8.57 & 9.36 \\
\hline Wheat farm surplus (M €) & 1.73 & 2.95 & 3.42 & 4.25 & 2.68 & 4.10 & 5.62 & 6.48 \\
\hline Sugar beet farm surplus (M $€$ ) & 1.14 & 1.39 & 1.55 & 2.78 & 0.70 & 1.63 & 2.06 & 2.86 \\
\hline Total Agricultural Surplus (4) (M €) & 2.88 & 4.34 & 4.98 & 7.04 & 3.38 & 5.73 & 7.68 & 9.35 \\
\hline Deadweight loss $(1-4=2-3-4)$ & 16.48 & 22.02 & 27.65 & 33.45 & 19.84 & 26.84 & 34.23 & 41.86 \\
\hline
\end{tabular}

Average ex-factory gasoline (premium unleaded $10 \mathrm{ppm}$ fob) cost in 2010 is 0.448 euro per litre; cost of gasoline for the amount of 11 ethanol equivalent is $0.448 \times 0.939=0.42$ euro

${ }^{a}$ Industry surplus is the difference between ethanol sales price and production cost. It depends on earmarked tax exemption from petroleum product taxes, which is assumed at 0.4 euro per litre or sales price at 0.82 euro per litre

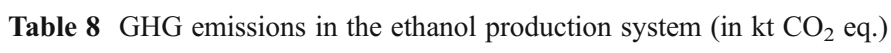

\begin{tabular}{|c|c|c|c|c|c|c|}
\hline \multirow[b]{2}{*}{ Plant capacity (kt) } & \multirow{2}{*}{$\begin{array}{l}\text { Index } \\
0\end{array}$} & \multicolumn{4}{|c|}{ CAP 2006 (subsidy on cotton at $55 € /$ ha) } & \multirow{2}{*}{$\begin{array}{l}\text { CAP2009 (subsidy on } \\
\text { cotton at } 80 € / \text { ha) }\end{array}$} \\
\hline & & 60 & 80 & 100 & 120 & \\
\hline \multicolumn{7}{|c|}{ Direct LUC (regional boundaries within Thessaly) (kt) } \\
\hline Net $\mathrm{CO}_{2}$ emission in agriculture & 1 & -20.5 & -28.2 & -37.5 & -45.2 & -32.7 \\
\hline Net $\mathrm{CO}_{2}$ in transportation & 2 & 0.47 & 0.65 & 0.86 & 1.05 & 1.2 \\
\hline Net $\mathrm{CO}_{2}$ emission from direct LUC & $3=1+2$ & -20.0 & -27.6 & -36.6 & -44.2 & -31.5 \\
\hline \multicolumn{7}{|l|}{$\begin{array}{l}\text { Indirect LUC (replaced food crops by imports and } \\
\text { substitution of imported soya cake) (kt) }\end{array}$} \\
\hline $\mathrm{CO}_{2}$ emission imported grains & 4 & 22.8 & 32.8 & 40.3 & 47.5 & 18.2 \\
\hline Net $\mathrm{CO}_{2}$ transport imported grains & 5 & 7.3 & 10.5 & 12.9 & 15.1 & 5.9 \\
\hline $\mathrm{CO}_{2}$ avoided reduced soya cake imp. & 6 & -31.7 & -42.2 & -52.8 & -63.4 & -63.4 \\
\hline Net $\mathrm{CO}_{2}$ emission from indirect LUC & $7=4+5+6$ & -1.6 & 1.1 & 0.4 & -0.8 & -39.3 \\
\hline \multicolumn{7}{|l|}{$\begin{array}{l}\mathrm{CO}_{2} \text { emission at the industrial transformation and } \\
\text { fuel consumption (kt) }\end{array}$} \\
\hline $\mathrm{CO}_{2}$ for electricity & 8 & 15.6 & 20.7 & 25.9 & 31.1 & 31.1 \\
\hline $\mathrm{CO}_{2}$ for steam & 9 & 71.9 & 95.8 & 119.8 & 143.8 & 143.8 \\
\hline Total $\mathrm{CO}_{2}$ for industrial processing & $10=8+9$ & 87.5 & 116.5 & 145.7 & 174.9 & 174.9 \\
\hline $\begin{array}{l}\mathrm{CO}_{2} \text { avoided from replaced gasoline ( } 0.939 \text { for } \\
1 \mathrm{t} \text { of ethanol) }\end{array}$ & 11 & -170.2 & -226.9 & -283.7 & -340.4 & -340.4 \\
\hline \multicolumn{7}{|l|}{ Total net $\mathrm{CO}_{2}$ emission $(\mathrm{kt})$} \\
\hline Direct LUC & $12=3+10+11$ & -102.7 & -138.0 & -174.6 & -209.7 & -197.0 \\
\hline Direct plus indirect LUC & $13=7+12$ & -104.3 & -136.9 & -174.2 & -210.5 & -236.3 \\
\hline \multicolumn{7}{|l|}{ Total net $\mathrm{CO}_{2}$ emission per ton of ethanol $(\mathrm{t})$} \\
\hline Direct LUC & $14=12 / 0$ & -1.712 & -1.725 & -1.746 & -1.747 & -1.642 \\
\hline Direct plus indirect LUC & $15=13 / 0$ & -1.424 & -1.395 & -1.427 & -1.438 & -1.653 \\
\hline \multicolumn{7}{|l|}{$\begin{array}{l}\text { Total and unitary cost of } \mathrm{CO}_{2} \text { saving for tax } \\
\text { exemption at } 40 \mathrm{c} \text { per litre }\end{array}$} \\
\hline Total cost of $\mathrm{CO}_{2}$ saving $(\mathrm{M} €)$ & 16 & 16.48 & 22.02 & 27.65 & 33.45 & 41.86 \\
\hline Cost saving direct LUC(€/t) & $17=16 / 12$ & 160.4 & 159.6 & 158.4 & 159.5 & 212.5 \\
\hline Cost saving direct + indirect $\operatorname{LUC}(€ / \mathrm{t})$ & $18=16 / 13$ & 157.9 & 160.9 & 158.7 & 158.9 & 177.1 \\
\hline
\end{tabular}


biodiesel effectiveness estimated by Iliopoulos and Rozakis (2010), bioethanol performs better than current and proposed biodiesel production schemes that require for $1 \mathrm{t}$ $\mathrm{CO}_{2}$ eq. saved about 300 and $160-250$ euros, respectively.

\section{Conclusions}

This paper attempts an evaluation of bioethanol production in the context of the ex-sugar industry in Thessaly, taking into consideration recent changes in the Common Market Organisation for sugar in the EU. We also intended to demonstrate the potential of mathematical programming for economic and environmental analyses of the material-product chains associated with the life cycle analysis of products.

An integrated model, articulating the agricultural supply of biomass with ethanol processing, maximises the total surplus under constraints, determining its costeffectiveness for different production levels. Based on the detailed bottom-up modelling of the agricultural sector, direct and indirect land use changes, which represent a significant part of total emissions, are taken into account for the estimation of the emissions differential; indirect land use change always results in a higher emissions balance. Two policy variants of the current CAP are examined. Economic performance and environmental cost-effectiveness of bioethanol are clearly affected by agricultural policy parameters, in this case, the area subsidy to cotton. In order to reduce GHG by 1 ton of carbon dioxide, the overall cost to the society equivalent means of bioethanol production varies between 160 and 212 euros. This cost decreases as far as agricultural policies move to more and more to the decoupling of subsidies from production. With regards to energy policies allocating different levels of tax exemption in favour of biofuels, the environmental cost-effectiveness is not affected, as the industry is the agent that captures the increased subsidised amounts.

Different technology configurations should be included in the integrated model to extend the feasible area of the optimisation problem. A notable feasible alternative is cogeneration with biogas within the bioethanol plant so that an electricity requirement can be met. The biogas unit can use DDGS and pulp as raw material, the by-product from ethanol production. In addition, additional technical configurations, including recent research findings on promising crops, such as sorghum (Maki 2007), could increase farmers' gains.

Further research should be conducted to take into account the uncertainty. Uncertainty issues, concerning not only the demand side (ethanol and by-products price volatility) but also the supply side (changing policy contexts and competitive crop price volatility), need to be addressed in order to determine the confidence levels of ethanol environmental cost-effectiveness.

Acknowledgments Thanks go to the Hellenic State Scholarships Foundation for funding the $\mathrm{PhD}$ thesis of M.I. Haque that supports this paper. Thanks also go to the EU Project "PROFICIENCY" FP7REGPOT-2009-1-245751 for funding the stay of M. Borzecka-Walker and K. Mizak with the Agricultural University of Athens that made possible their contribution to this work. Comments raised by the referees and the editor are highly appreciated. Thanks are also given to Colin Walker for his English proofreading and editing.

Open Access This article is distributed under the terms of the Creative Commons Attribution License which permits any use, distribution, and reproduction in any medium, provided the original author(s) and the source are credited.

\section{References}

Anonymous (2006) Mallow sugar factory ethanol production evaluation study, Cork County Council. Cooley-Clearpower Research, 4 Merrion Square, Dublin

BioGrace (2010) BioGrace project GHG calculations, version 4public

Börjesson P (2009) Good or bad bioethanol from a greenhouse gas perspective - what determines this? Appl Energ 86:589-594

Brentrup F, Kusters J, Lammel J, Kuhlmann H (2000) Methods to estimate on-field nitrogen emissions from crop production as an input to LCA studies in the agricultural sector. Int J Life Cycle Assess 5:349-357

Bzowska-Bakalarz M, Ostroga K (2010) Assessment of chances for keeping sugar beet production in Lubelskie voivodeship. Agric Eng 6(124):5-11

Cherubini F, Jungmeier G (2010) LCA of a biorefinery concept producing bioethanol, bioenergy, and chemicals from switchgrass. Int J Life Cycle Assess 15(1):53-66

DEFRA (2010) Guidelines to Defra/DECC's GHG conversion factors for company reporting. In: F.A.R.A. (ed) Department for environment. Government of UK

Dorin B, Gitz O (2008) Ecobilans des biocarburants: une revue des controverses. Natures Sciences Sociétés 16:337-347

EC (2005) Reforming the European Union's sugar policy: update of impact assessment. Commission Staff Working Document, Commission of the European Communities, Brussels

Haque MI, Rozakis S, Ganko E, Kallivroussis L (2009) Bio-energy production in the sugar industry: an integrated modeling approach. Paper presented at the 113th EAAE Seminar "A resilient European food industry and food chain in a challenging world", Chania, Crete

Icoz E, Tugrul KM, Saralb A, Icoz E (2009) Research on ethanol production and use from sugar beet in Turkey. Biomass Bioenergy $33: 1-7$

Iliopoulos C, Rozakis S (2010) Environmental cost-effectiveness of biodiesel production in Greece: current policies and alternative scenarios. Energ Policy 38:1067-1078

IPCC (2006) $\mathrm{N}_{2} \mathrm{O}$ emissions from managed soils and $\mathrm{CO}_{2}$ emissions from lime and urea application, IPCC Guidelines for National Greenhouse Gas Inventories

Kløverpris J, Wenzel H, Banse M, Milà i Canals L, Reenberg A (2008a) Global land use implications of biofuels: state-of-the-art conference and workshop on modelling global land use implications in the environmental assessment of biofuels. Int J Life Cycle Assess 13:178-183 
Kløverpris J, Wenzel H, Nielsen PH (2008b) Life cycle inventory modelling of land use induced by crop consumption: part 1: conceptual analysis and methodological proposal. Int J Life Cycle Assess 13:13-21

Koga N (2008) An energy balance under a conventional crop rotation system in northern Japan: perspectives on fuel ethanol production from sugar beet. Agric Ecosyst Environ 125:101-110

Lechon Y, Cabal H, Saez R (2011) Life cycle greenhouse gas emissions impacts of the adoption of the EU directive on biofuels in Spain. Effect of the import of raw materials and land use changes. Biomass Bioenergy 35:2374-2384

Lewandowski I, Kicherer A, Vonier P (1995) $\mathrm{CO}_{2}$-balance for the cultivation and combustion of miscanthus. Biomass Bioenergy 8:81-90

Lychnaras V, Rozakis S (2006) Economic analysis of perennial energy crop production in Greece under the light of the new CAP. New MEDIT 5:29-37

Macedo IC, Seabra JEA, Silva JEAR (2008) Green house gases emissions in the production and use of ethanol from sugarcane in Brazil: the 2005/2006 averages and a prediction for 2020. Biomass Bioenergy 32:582-595

Maki G (2007) Economic evaluation of Larissa sugar factory conversion to ethanol. MBA programme in the Agribusiness Management. Agricultural University of Athens, Athens

Malça J (2002) Biofuel production systems in France: a resource assessment, prepared for Economie et Sociologie Rurales. Unité Mixte de Recherche d'Economie Publique, Institut National de la Recherche Agronomique (INRA). Thiverval-Grignon, France and Coimbra Polytechnic Institute, Portugal

Malça J, Freire F (2010) Uncertainty analysis in biofuel systems. J Ind Ecol 14:322-334

Malca J, Freire F (2011) Life-cycle studies of biodiesel in Europe: a review addressing the variability of results and modeling issues. Renew Sustain Energy Rev 15:338-351

Mavrotas G, Rozakis S (2002) A mixed 0-1 MOLP approach for the planning of biofuel production. Options Méditerannéenes Serie A (48):47-58

Murphy JD, McCarthy K (2005) Ethanol production from energy crops and wastes for use as a transport fuel in Ireland. Appl Energy 82:148-166
Nguyen TLT, Gheewala SH (2008) Life cycle assessment of fuel ethanol from cassava in Thailand. Int J Life Cycle Assess 13(2):147-154

Ngyen MH, Prince RGH (1996) A simple rule for bioenergy conversion plant size optimisation: bioethanol from sugar cane and sweet sorghum. Biomass Bioenergy 10:361-365

Rozakis S, Danalatos N, Tsiboukas K (2001) Crop rotation in Thessaly: bio-economic modelling for efficient management. Medit 4:50-57

Russi D (2008) An integrated assessment of a large-scale bio diesel production in Italy: killing several birds with one stone? Energ Policy 36:1169-1180

Scacchi CCO, González-García S, Caserini S, Rigamonti L (2010) Greenhouse gases emissions and energy use of wheat grainbased bioethanol fuel blends. Sci Total Environ 408:5010 5018

Searchinger T, Heimlich R, Houghton RA, Dong F, Elobeid A, Fabiosa J, Tokgoz S, Hayes D, Yu T-H (2008) Use of US croplands for biofuels increases greenhouse gases through emissions from landuse change. Science 319:1238-1240

Soldatos P, Kallivroussis L (2001) Conversion to ethanol from beets and grain. In: Varela $\mathrm{M}$ et al (eds) Energy crops integration using a multiple criteria decision-making tool. CIEMAT

St. Clair S, Hillier J, Smith P (2008) Estimating the pre-harvest greenhouse gas costs of energy crop production. Biomass Bioenergy $32: 442-452$

Treguer D, Sourie J-C (2006) The impact of biofuel production on farm jobs and income, the French case. Proceedings of the 96th EAAE seminar in Tanikon, Switzerland

Tsoutsos T, Kouloumpis V, Zafiris T, Fotinis S (2010) Life cycle assessment for biodiesel production under Greek climatic conditions. J Clean Prod 18:328-335

Warnock K, Dickinson A, Wardlow GW, Johnson DM (2005) Ethanol 85 (E-85) versus unleaded gasoline: comparison of power and efficiency in single cylinder, air-cooled engines. National AAAE Research Conference - Poster Session

Wicke B, Dornburg V, Junginger M, Faaij A (2008) Different palm oil production systems for energy purposes and their greenhouse gas implications. Biomass Bioenergy 32:1322-1337 